МАСЛИКОВ Вадим Александрович - кандидат социологических наук, доцент кафедры политологии и социологии Российского экономического университета им. Г.В. Плеханова (117997, Россия, 2. Москва, Стремянный пер., 36; Virtu69@таil.ru)

\title{
ПОДХОД К ИССЛЕДОВАНИЮ ИДЕНТИФИКАЦИОННО-ИНТЕГРАЦИОННЫХ ПРОЦЕССОВ НА ПРИМЕРЕ РОССИЙСКО- ЛИТОВСКИХ ОТНОШЕНИЙ
}

\begin{abstract}
Аннотация. В статье рассматривается подход к исследованию идентификационно-интеграционного потенциала Литвы как одной из сложных, недавно образованных формально независимых стран. Данный подход основан на концепции национальной идентичности Стивена Шульмана, которая представляет национальную идентичность в качестве многоуровневой системы. Исходя из результатов такого анализа, автор предлагает направления развития взаимодействия между странами.
\end{abstract}

Ключевые слова: идентификационно-интеграционные процессы, индекс национальной идентичности, ценности, социокультурные факторы

Л итва является одной из 15 некогда «сестер»- республик канувшего в Лету Союза Советских Социалистических Республик. Но, в отличие от подавляющего большинства других «сестер», Литва имела исторические основания для своего державного суверенитета. Вероятно, эта латентная, подспудная убежденность в справедливости своих требований руководила советскими гражданами Литовской ССР в отстаивании всех тех свобод, которых они не имели в Союзе. В первую очередь это были свободы духовного и социокультурного порядка - именно они в коммунистической стране считались крамольными, т.к. противоречили духу марксизма-ленинизма, воинствующего атеизма и, помимо позитивных функций, «подсвечивали ауру» национального шовинизма.

Более трех десятилетий прошло с тех пор. На основании объективных данных в основных областях государственного и общественного развития такой временной отрезок позволяет сделать некоторые выводы об успешности выбранного пути. Он позволяет попытаться понять, происходит ли процесс поиска места Литвы и ее общества в окружающем мире, определилась ли Литва в своей национальной идентичности, а значит, видит ли она цели и идеальные формы своего будущего, и каков он, образ будущего Литвы, а значит и то, с кем приходится иметь дело России и как выстраивать свои соседские отношения.

Национальная идентичность основана на возможности определения степени своего сходства с разными социальными группами и общностями при одновременном видении своей уникальности и неповторимости. Согласно концепции С. Шульмана, национальная идентичность определяется совокупностью индикаторов, определяющих этническую, гражданственную и культурную составляющие общественного организма (см. табл. 1, 2).

С. Шульман, описывая сущностные характеристики национальной идентичности, выделял три звена, составляющих ее содержание, которые он идентифицировал как «факторы, которые представители той или иной нации считают наиболее значимыми для их объединения, а также дифференциации их от представителей других партий, факторы, которые и являются в конечном счете основой идентификации с данной партией» [Shulman 2002: 559]. Эти три 
направления определены С. Шульманом как гражданская, культурная и этническая идентичности.

Сборка пазлов этой идентичности ведется в Литве усиленными темпами все постсоветские десятилетия. Механизм такой сборки основан в первую очередь на заградительных мерах, насильственном «олитвинивании», а также делегитимации в первую очередь популярной русской культуры. Наблюдаемые параллельно меры навязывания западных ценностей, мировоззренческих установок, языковой картины мира, лингвистических императивов, культурных образцов поведения носят ярко выраженную искусственную вестернизацию. Такая политика продолжает только лишь усиливаться, даже несмотря на свою причинную обусловленность массовым оттоком граждан Литвы на Запад, что приводит к очевидному упадку Литвы.

Предварительный анализ основных характеристик развития Литвы позволяет сделать попытку анализа сумм индикаторов идентичности С. Шульмана в приложении к основным как современным, так и историческим аттракторам литовской социальной системы, которыми традиционно за годы существования Литвы являлись такие наднациональные модели, как Великороссия, Речь Посполитая, западная модель (некогда тевтоны, а ныне - ЕС и США).

Особым образом следует отметить активное движение некоторых стран в направлении второго аттрактора. При этом в отечественной и мировой информационной повестке реваншистским амбициям Польши не уделяется достаточно серьезного внимания. Тем временем проекту V4 (Вышеградское объединение) 15 февраля 2021 г. исполнилось 30 лет, и за все эти годы он не только не потерял актуальность, но и поэтапно, в полном соответствии с планами, вполне успешно развивается. Более того, несмотря на и без того самую крупную в Европе проектируемую государственную агломерацию, за эти годы амбиции Польши по присоединению новых территорий регулярно презентируются мировому сообществу, не получая при этом никакого заметного политического отпора.

Определенные интересы в новой Речи Посполитой имеет правительство Литвы: с одной стороны, это соответствует исторической памяти, а значит будет с пассионарным воодушевлением воспринято населением; с другой такая позиция в полной мере соответствует стратегии усиления «Петли анаконды» - глобального плана по удушению России, что также соответствует современной политической линии Литвы в отношении России.

Постольку поскольку в этом поэтапно реализуемом проекте (через политически транзитную Вышеградскую группу) вписаны территории не только Прибалтики, но и исторически небезразличных для России Украины, Белоруссии, Молдавии, данное политическое моделирование представляет для России достаточно серьезный интерес и должно пристально рассматриваться в особом порядке.

Другая альтернативная ущербной концепции ЕС форма дальнейшей интеграции Литвы - возвращение в Россию. Многие аналитики считают в настоящее время такой вариант развития событий недостаточно реалистичным. Однако некоторые из них опираются на то, что Москва рассматривает Прибалтику и, в частности, Литву как «временно потерянную территорию» (игнорируя при этом обратный интерес), что одушевляет данный проект. Кроме того, в отличие от химеричной Речи Посполитой, современная Россия - реальное мощное, динамично развивающееся государство, имеющее свою суверенную идеологическую платформу, закрепленную в Конституции 2020 г. и являющуюся противопоставлением весьма сомнительной для народа Литвы западной гипертоле- 
рантной идеологии ${ }^{1}$, хотя и весьма созвучной с польской. Предположительный вес индексов национальной идентичности в приложении к основным аттракторам литовской политической интеграции представлен в табл. 1.

Таблица 1

\section{Индексы национальной идентичности С. Шульмана в приложении к основным аттракторам литовской политической интеграции}

\begin{tabular}{|l|c|c|c|}
\hline \multirow{2}{*}{ Виды идентичности } & \multicolumn{3}{|c|}{ Основные аттракторы } \\
\cline { 2 - 4 } & EС, США & $\begin{array}{c}\text { Речь } \\
\text { Посполитая }\end{array}$ & Россия \\
\cline { 2 - 4 } & \multicolumn{3}{|c|}{ Потенциал индикаторов } \\
\hline Гражданская & 2 & 1 & 1 \\
\hline общность территории; гражданства & 1 & 1 & 1 \\
\hline $\begin{array}{l}\text { приверженность системе политических } \\
\text { принципов }\end{array}$ & 1 & 2 & 2 \\
\hline приверженность идеологии & 1 & 1 & 0 \\
\hline $\begin{array}{l}\text { доверие к политическим институтам и } \\
\text { равенство политических прав }\end{array}$ & 2 & 1 & 1 \\
\hline желание и согласие быть частью нации & \multicolumn{3}{|c|}{} \\
\hline Культурная & 1 & 1 & 1 \\
\hline язык & 2 & 2 & 1 \\
\hline религия & 1 & 2 & 2 \\
\hline традиции & \multicolumn{3}{|c|}{} \\
\hline Этническая & 0 & 1 & 1 \\
\hline происхождение & 1 & 2 & 2 \\
\hline раса & 12 & 14 & 12 \\
\hline Итого & \multicolumn{2}{|c|}{} \\
\hline
\end{tabular}

Важно добавить, что индикаторов С. Шульмана для полномерной оценки рассматриваемых тенденция недостаточно, поскольку они в большей степени ориентированы на оценку такой социальной проблемы, как миграционные процессы. Весьма значительную роль в интеграционных вопросах играет и ряд других факторов, связанных с рассматриваемыми выше параметрами самой социально-политической системы, условиями ее метасистемы и граничащих с ней социальных систем. Эти дополнительные индикаторы рассмотрены в табл. 2.

Следует отметить, что данные оценки достаточно условны и построены на результатах анализа косвенных социально-политических исследований, однако они дают представление о современном состоянии и возможных тенденциях интегративного движения литовского общества и государства при гипотетическом условии обретения ими суверенитета.

При этом вес дополнительных факторов не состоит из сумм подфакторов, оттого его сложно линейно сравнивать с суммой факторов С. Шульмана до тех пор, пока не будет установлена методологическая взвешенность всех индикаторов. Кроме того, при такой оценке совокупность факторов следует разделить

1 DieWelt (Германия): слова папы о гомосексуальных союзах потрясли церковь. Доступ: https://inosmi.ru/religion/20201022/248385878.html (проверено 15.07.2021). 
Таблица 2

Индексы национальной идентичности С. Шульмана и дополнительные факторы в приложении к основным аттракторам литовской интеграции

\begin{tabular}{|l|c|c|c|}
\hline \multirow{2}{*}{ Виды идентичности } & \multicolumn{3}{|c|}{ Основные аттракторы } \\
\cline { 2 - 4 } & EC, США & $\begin{array}{c}\text { Речь } \\
\text { Посполитая }\end{array}$ & Россия \\
\cline { 2 - 4 } & \multicolumn{3}{|c|}{ Потенциал индикаторов } \\
\hline \multicolumn{2}{|c|}{ Дополнительные идентификационно-интеграционные факторы } \\
\hline \multicolumn{1}{|c|}{$\mathbf{1 2}$} & 14 & $\mathbf{1 2}$ \\
\hline Географический & 0 & 1 & 2 \\
\hline Исторический & 0 & 1 & 2 \\
\hline Экономический & 2 & 1 & 2 \\
\hline Социальный & 1 & 1 & 1 \\
\hline Социокультурный & 1 & 2 & 2 \\
\hline Военно-политический & 1 & 0 & 1 \\
\hline Итого & $\mathbf{5}$ & $\mathbf{6}$ & $\mathbf{1 0}$ \\
\hline
\end{tabular}

на две основные группы: в первой группе имеют право находиться факторы явные, такие как географический и экономический, а во второй - экзистенциальные, связанные с базовыми ценностями общества, его жизненными смыслами, идеалами и целями, устойчивыми традициями, культурными образцами. При этом вторая группа факторов имеет стратегическое значение, но она более инертна и ригидна, не проявляется повседневно, хотя и определяет загоризонтную повестку развития.

Исходя из описанного выше, намеченная методика представляет интерес для оценки тенденции политической интеграции и при необходимости позволяет углубиться в разработку и обоснование методологии оценки идентификационно-интеграционных процессов в динамично меняющемся политическом пространстве.

Кроме того, проведенный таким образом анализ позволяет обнаружить достаточно значимые для внимания векторы социально-политической интеграции литовского общества. Россия в них играет большее значение, чем это может показаться, а значит, политика России по отношению к Литве должна учитывать актуальные сильные латентные факторы.

Исходя из представленного социально-политического расклада, следует определить основные тенденции и пути развития двусторонних связей России с Литвой. Эти направления целесообразно представить в классическом порядке общественных сфер - от экономической до духовной.

«Политика - искусство жить вместе, то есть искусство сосуществования», говорил Платон. При этом слово «жить» далеко от слова «воевать». Поэтому в сфере экономического взаимодействия если со стороны России будут исходить меры, исключительно, без разбора подавляющие литовскую экономику, то будет создаваться образ России как злобного агрессора, желающего крови и горя бедным слабым соседям. Это создает прекрасную базу для антироссийской пропаганды во всем мире.

Экономическая политика по отношению к Литве (и не только) должна быть 
исключительно понятной и справедливой - ни одной крохи с русского стола не перепадет русофобам, но достойное место за нашим столом всегда найдется настоящим друзьям. Это правило должно касаться каждого бизнесмена, пожелавшего обратиться в сторону России, а значит потенциального проводника российских интересов. Все экономические контакты должны иметь ясно выраженный политический характер - лояльность дает преимущества и стоит денег.

Если будет создан прецедент выгодного морально устойчивого бизнеса, то будет создана модель, которая не только сможет сыграть существенную роль в налаживании справедливых отношений в Литве, но и стать притягательной в мире. Принципы таких отношений будут основой создания новых мировых институтов международных отношений и интеграций.

В социальной сфере, как и в остальных, основная проблема в том, что там, по сути, правит оккупационная элита, не руководствующаяся интересами населения Литвы (уничтожение отечественной энергетики - Игналинской АЭС, промышленности, транзитных и других добрососедских возможностей развития как ответ на агрессивную русофобию, навязывание не соответствующих национальным ценностям идеологических установок гипертолерантности и нацизма и т.д.). Для разрешения этой проблемы в идеале следует «деоккупировать» все социальные институты, особенно образования и воспитания, культуры, массовой коммуникации и информации, семьи и брака, внутренней и внешней политики, а на их месте создать свои социальные институты, отвечающие национальной системе базовых ценностей литовского народа.

Россия должна всемерно способствовать этому. Но и после национально ориентированного восстановления работы социальных институтов должно пройти время очищения от оккупационных идеологических установок западной манипуляции. Этого народу Литвы никто не позволит; без помощи России скорее всего люди будут выезжать в поисках лучшей жизни, а страна - вымирать. Поэтому проблема угасания Литвы будет связана с проблемой европейской интеграции до тех пор, пока эта не самая оптимальная форма международной интеграции будет существовать, и Литва будет нужна глобальному Западу в качестве босого и голодного велита, трясущего дротиком.

Однако, несмотря на то что современных литовцев запугивают военной оккупацией России и обязательными ГУЛагами, даже когда литовское общество вновь выразит интеграционное стремление к нам, спешить не стоит. Не стоит спешить потому, что, во-первых, у России нет острой потребности в присоединении Литвы; а во-вторых, теперь, после достаточно длительной антирусской пропаганды, надо, чтобы в Литве были приняты соответствующие меры по восстановлению доброго почитания слова «русский» в литовской культуре, как это было у их более мудрых предков. Паразиты и ненадежные союзники России не нужны, России нужны сотворцы общего светлого будущего.

Политическая сфера. Во внутренней российской информационной повестке важно четко закрепить разницу между антинародным управлением Литвы и базовыми ценностями литовцев, синхронными с нашими; показывать события в Литве не с издевкой и улюлюканьем, а с братским сопереживанием по отношению к утратившими принципы объективного восприятия действительности, информационно зачумленным соседям.

Следует оказывать максимальное содействие в первую очередь официальным литовским политикам и политическим объединениям, склонным к лояльности по отношению к России, а также некоммерческим организациям - общественным, научным, журналистским, образовательным, культурным, кинематографическим, юридическим, спортивным. Эта деятельность требует 
стратегии, нужны разного рода гранты, проекты... Чрезвычайно важно, чтобы было больше русского позитива - прибалты должны твердо знать, что к ним «солнце_приходит_из_России», а их шпроты любят на Востоке. Требуется стратегия по формированию исключительно позитивного образа русского солнца, не желающего поглотить Литву, а способного греть ее за то, что она почитает Россию.

С традиционной военно-политической точки зрения Литва не представляет стратегической угрозы в качестве исчезающего донатщика ЕС, однако в случае смены социокультурной и политической ориентации на $V 4$ или Речь Посполитую появляется сигнал о завершающей стадии воплощения агрессивного по отношению к России блока - передового легиона и зачинщика НАТО.

Социокультурная, духовная сфера основывается на базовых ценностях народа, а значит в силу своей культурной легитимации нормативного порядка является нормополагающей, определяющей развитие всех остальных сфер общественного устройства. Кроме того, эта сфера наиболее консервативна и инертна в восприятии новых социальных аттитюдов и моделей поведения. Развивать отношения в области религиозного, социокультурного, образовательного секторов достаточно сложно, но крайне важно [Масликов 2015].

Двухсторонние связи в этой области следует развивать только на основе базовых ценностей, особенно социокультурные. Конечно же, это и разностороннее религиозное взаимодействие, и доступный прокат нашего кинематографа, и не обремененный финансовой доходностью обмен культурными, образовательными, информационными программами, но также и экономические контакты исключительно с проверенным лояльным России деловым сообществом. Необходимо использовать как внутренние, так и внешние каналы для популяризации здоровых социокультурных течений в Литве, для обнажения и опровержения неправды, всех источников, интересантов и последствий деятельности русофобских, нацистских и «гипертолерантных» организаций и персон.

Также достаточно важно заметить, что России как великой державе ни в коей мере нельзя уподобляться психологии малой собачки, отвечающей лаем на лай. Так, к примеру, было бы правильно акцентировать внимание не на том, что в Литве запрещают слова «мама» и «папа», а на том, что, поскольку Литва - территория ценностей русского мира, ее общество так же, как и российское, выступило против извращенных западных социокультурных установок. Также Россия должна настойчиво возвращать в мировую политику базовые цивилизационные принципы, основанные на идеях стремления к добру, а не конкуренции.

Таким образом, следует отметить, что, несмотря на не самые лучшие времена, России и ее народу небезразлично развитие двусторонних отношений с Литвой, имеющих богатую многовековую историю. Отношения, к которым Россия стремится, достаточно основательно выразил президент России В.В. Путин: «Здесь важно только одно: нужно подходить к диалогу по-честному. Нужно избавиться от фобий прошлого. Избавиться от того, чтобы использовать во внутриполитических процессах все проблемы, которые нам достались из прошлых веков, а смотреть в будущее. <... Мы к этому готовы, мы этого хотим, мы будем к этому стремиться. Но любовь невозможна, если она декларируется только с одной стороны, она должна быть взаимной» 1 .

1 «Есть риск борьбы всех против всех». Путин выступил на Давосском форуме. Доступ: https://ria.ru/20210127/davos-1594798218.html (проверено 15.07.2021). 


\section{Список литературы}

Масликов В.А. 2015. О методологии социокультурного исследования. Материалы Ивановских чтений. № 5(5). С. 363-376.

Shulman S. 2002. Challenging the Civic/Ethnic and West/East Dichotomies in the Study of Nationalism. - Comparative Political Studies. Vol. 35. No. 5. P. 554-585.

MASLIKOV Vadim Aleksandrovich. Cand.Sci. (Soc.), Associate Professor of the Chair of Political Science and Sociology, Plekhanov Russian University of Economics (36 Stremyanny Lane, Moscow, Russia, 117997; Virtu69@mail.ru)

\section{AN APPROACH TO THE STUDY OF IDENTIFICATION AND INTEGRATION PROCESSES ON THE EXAMPLE OF RUSSIAN-LITHUANIAN RELATIONS}

Abstract. The article considers an approach to the study of the identification and integration potential of Lithuania as one of the most complex newly formed formally independent countries. This approach is based on the concept of national identity by Stephen Shulman, which presents national identity as a multi-level system. Basing on the results of this analysis the author proposes the directions for the development of cooperation between the countries.

Keywords: identification and integration processes, national identity index, values, socio-cultural factors 